logos_i_ethos_2015_1_(38), s.93-130

DOI: http://dx.doi.org/10.15633/lie.1047

Anna M. Rowan

Pontifical University of John Paul II in Krakow

\title{
The relationship between will and reason in the moral philosophies of Kant and Aquinas
}

One of the perennial questions in moral philosophy is how or where to find the ultimate foundation of morality. Do we ground it in human nature, and if so, in what aspect of human nature? Do we ground it in human inclinations, appetites, emotions, and desires? Or should we ground it reason alone? Should the fundamental basis of the moral worth of human actions be pleasure or utility with their frequently unfortunate or even cruel effects? Or, in order to prevent these, should we go to the other extreme and try to ground human moral action in reason alone? Do we ground moral action in duty? ${ }^{1}$ But then how to define duty? Or do we try to define the moral worth of action by its consequences? ${ }^{2}$ But then how do we determine the moral value of consequences? What makes them good or bad or evil? For whom are they good or bad? Ultimately, it seems that we cannot avoid going back to trying to establish the metaphysical ground for the moral worthiness of action.

We need to ask ourselves whether and to what extent human nature can provide the foundation of moral action. And if it does, we need to
Anna M. Rowan - doktorantka na Wydziale Filozofii Uniwersytetu Papieskiego Jana Pawła II w Krakowie. Otrzymała stopień 'Bachelor of Arts' z biologii molekularnej i filozofii, i stopień 'Master of Arts' z filozofii, na Uniwersytecie Kolorado w Boulder. Wykładała filozofię na Front Range College w Kolorado. Zajmuje się również poradnictwem filozoficznym. Zainteresowania: metafizyka i ontologia w szczególności jako podstawy etyki, filozofia człowieka i filozofia umysłu.

1 Deontological ethics - the basic idea is that the moral worth of an action is judged by its adherence to a rule or set of rules. Kant's ethics is the perfect of example of deontological ethics.

Consequentialism - the basic idea is that the moral worth of an action is judged by its consequences. Examples of consequentialism include pragmatism and utilitarianism. 
search for the most ontologically sound account of human being, one that would allow the grounding of moral action in human being and, to this extent, provide the criterion of moral worthiness of action. These are the questions that guide the thoughts and analyses presented in this essay. It is, however, not an essay in normative ethics. Its main goal is to assess Aquinas' and Kant's solutions to finding the metaphysical foundation of morality. I will focus primarily on their notions of will and, to a lesser degree, their implications for the criterion of the moral worth of an action. However, to the extent that for both Kant and Aquinas the notion of will is inextricable from the notion of reason, the focal point of my analysis will be the relationship between will and reason in their philosophies.

In the first part of this essay I will focus on Kant. After giving a general outline of his notion of reason, I will analyze his concept of the good will. The second part of this essay will be dedicated to an extensive discussion of Aquinas' analysis of the intellect and the will and their interplay in the human act. The main reason for the more detailed discussion of Aquinas's notion of the rational appetite is the complexity of the concept in the sense that it cannot be divorced from the totality of human nature. Finally, I will discuss and assess their respective notions of will and reason in regard to providing the metaphysical foundation for the criterion of moral action. My contention is that Aquinas' analysis of the will and its relation to reason is superior to that of Kant in two respects: first, phenomenologically; and second, in providing the foundation for a criterion of morality.

\section{Will and reason in Kant's philosophy}

\subsection{Kant's dilemma}

Kant's goal in the Groundwork of the metaphysics of morals ${ }^{3}$ is to establish the absolute moral principle. He claims that if there is such an ultimate moral principle it must be found in reason alone and it cannot be

3 I. Kant, Groundwork of the metaphysics of morals [= GMM], transl. H. J. Patton, New York 1964 . 
related to anything in the empirical [phenomenal] world. Why is he so adamant about his position? Kant's relentless search for certainty with regard to the possibility of science can be best understood in the context of the battle between the rationalism of Leibnitz and empiricism of Hume. ${ }^{4}$ However, it was primarily Hume's total skepticism about the possibility of truth and of the objectivity of morality that propelled Kant out of his 'dogmatic slumber' ${ }^{5}$ to create his own philosophical edifice which was supposed to provide a firm philosophical foundation to both empirical science and morality. This foundation is to be found ultimately in reason. But Kant's notion of reason will differ from reason as understood previously by either rationalists or empiricists. Reason may not be able to reach reality as Leibnitz had hoped; nevertheless, reason is more than ordering of sense impressions as Hume had argued. The certainty of scientific truth cannot be found in rational inquiry, which is devoid of material content, but neither can it be based on experience because experience by its nature is purely subjective. Reason is to provide solid objective grounding to scientific inquiry. But Kant will also argue that rational inquiry has its limits. These are ultimately the limits of the universal structures of the human mind which impose forms onto all sensory data a human being experiences. To put it simply, the senses supply the material content of experience and the mind imposes forms onto those data.

Our sensory experience is always structured by what Kant calls the pure intuitions of space and time, that is, we always experience 'things' in space and time. These primary data are further organized by our minds, more precisely they are organized under the so-called categories of understanding, of which causality, multiplicity, or unity are examples. What this basically means is that the human mind is in total control both of structuring and of understanding reality; however, this does not imply that human experience of reality is purely subjective in the sense of individual subjectivity. It is subjective in the sense of being structured

4 Id., Critique of pure reason, transl. N. Kemp Smith, New York 1965, Preface to the first edition, p. 7-15; R. Scruton, Kant: a very short introduction, Oxford 2001.

Ibid., p. 25. 
by the human mind, but to the extent that the organizing principles are the principles of reason in its pure 'a priori' form they are objective. They are the only ways in which we can understand reality and so they are also the conditions that make empirical science possible. Basically, Kant's reaction to Hume's skepticism is to make the principles of experiencing and understanding physical reality independent of the individual subjective experience of that reality. In order to prevent any future skepticism with regard to science, he grounds the conditions of empirical science in reason in its pure 'a priori' form, which effectively boils down to proposing the conditions that makes any human experience of reality possible. And because these conditions are inherent structures of human mind per se they are universal to all rational beings.

In contrast to Hume's, Kant's notion of reason is more than the 'switchboard' because by providing universal [inherent to all humans] forms of interpreting sensory data, it is not purely subjective. For Kant, pure reason provides the transcendental ${ }^{6}$ ground of all human experience. We cannot ever touch the world of things-in-themselves. The neumena will always be outside of our reach but we can still have knowledge of the material objects in the world, not as they are in themselves but as we experience them.

Kant's ingenious solution to the extremes of both rationalists' and empiricists' epistemological approaches stems from his paying attention to both aspects of human experience, matter and form. The phenomenal world supplies material content and the human mind gives it form. Even if human reason may not be able to penetrate absolute reality, it still can have scientific knowledge of the physical world by imposing form onto matter. This is Kant's so-called 'Copernican revolution'. However, it can be argued that Kant, in fighting Hume's skepticism, envelops himself in another form of skepticism, one about the capacity of reason to reach the truth about reality and being, a kind of skepticism which is a total anathema to, for example, the approaches to reason of Aristotle and Aquinas.

6 To put it most simply, Kant uses the term "transcendental" to denote the ultimate condition of the possibility of human experience, or in the case of pure practical reason, of action. 
I will not continue with discussion of general aspects of Kant's philosophy but it is safe to say that Kant's moral philosophy is a natural outcome of the rest of his philosophy. Kant's fear about a lack of possibility of solid grounding for science bleeds over to his fear about the solid foundation of morality. Hume's arguments ${ }^{7}$ not only undermined the existence of the law of causality and thus the possibility of empirical science, but his moral philosophy belittled the role of reason in moral action and made morality dependent entirely on human emotion, specifically on sympathy. ${ }^{8}$ Hume threatened reason as the traditionally firm grounding of both science and morality. If Kant's response in The critique of pure reason is to establish the conditions that make empirical science possible, in the Groundwork of the metaphysics of morals he sets out to establish the absolute principle of morality.

This means that just as the principles of science must be made independent of an individual subject's experience of the physical world, similarly the principle of morally worthy action must be independent of anything belonging to the phenomenal world. In order for the ultimate principle of morality to have any objective force it must be necessary and universal which means it cannot be rooted in anything contingent. All human desires, inclinations, and wishes are rooted in human nature that belongs to the phenomenal world and so they are contingent. Therefore the ultimate moral principle must be established by reason alone, specifically reason in its 'a priori' form. And by grounding it exclusively in reason, Kant is also able to expand his absolute moral principle to include all rational beings of which humans are examples par excellence.

But the tragedy of a human being is that he stands between the world of matter and of things-in-themselves. His physical nature, inclinations, and desires keep him tied to the physical world of causal chains. But he

D. Hume, Enquiry concerning human understanding, [w:] The english philosophers of the $17^{\text {th }}$ and $18^{\text {th }}$ centuries, New York 1910 (Harvard Classics, 37, ed. Ch. W. Eliot), https://ebooks. adelaide.edu.au/h/hume/david/h92e/.

$8 \quad$ F. Coppleston, A history of philosophy, v. 5, Ch. 16 (3), London 1991. 
also experiences himself as an agent. He feels he can choose and he feels that he is free to choose between alternative options. Even if this freedom to choose may turn out to be an illusion with respect to his choices in following his desires, it must never be an illusion with respect to moral action. Morality presupposes freedom. But where does this freedom come from? It cannot come from his physical nature or the phenomenal world, which are governed by physical laws. This freedom cannot be explained by his rational faculty because of reason's limits to reach absolute reality. But freedom is necessary for morality and thus freedom becomes the postulate of pure reason in its practical function. Practical reason, whose function is directed also towards moral action, must postulate freedom as the ultimate basis of morality, despite reason's incapability of ever proving the absolute reality of this freedom. And along with freedom, practical reason postulates also God and immortality as further safeguards of morality.

This is the basic gist of Kant's argument for the foundation of morality. Freedom is the postulate of reason and it serves as the absolutely necessary grounding of morality. But this still leaves the problem of what provides the foundation for a moral action. As presented by Kant, freedom appears empty. True, it is the absolute foundation of the possibility of morality, but what is also needed is the foundation for the individual moral action. And this comes under the guise of 'good will' whose meaning, as it turns out, is fulfilled by reason in the role of legislator of the moral law "The Categorical Imperative." In the following section I will describe Kant's journey to establish his notion of morally worthy action.

\subsection{Kant's good will}

Even though Kant ultimately grounds morality in reason, he begins his inquiry with the notion of good will which for him "can be taken as good without any qualification". 9 Any other human good, be it 
intelligence, wealth, or courage, which is usually considered as desirable by people, can become harmful unless there is a good will to guide its use. Let us examine in more detail what Kant means by a good will. He says that a "a good will is not good because of what it effects or accomplishes, ... it is good through its willing alone - that is good in itself." ${ }^{10}$ Thus a good will is good not because it wills the good, as that would tie it to a possible outcome of an action, but it is good simply by virtue of its willing alone and it remains good irrespective of the outcome of an action. In this context Kant also argues that the only proper function of reason with respect to moral actions is not to guide us towards happiness or another end of human action since "...the end in question could have been maintained far more surely by instinct than it ever can be by reason." Instead, he claims that the only "true function of reason must be to produce a will which is good, not as a means to some further end, but in itself". ${ }^{12}$ Effectively, Kant completely divorces good will, that is, will in its moral function, from anything that usually motivates human actions, be it happiness, pleasure, or glory. In fact he severs it from any end of a human action.

But will has to be defined somehow, that is, its activity has to relate to something. As Aristotle points out, we do things for the sake of something, that is, our actions are directed towards obtaining some goal, be they pleasure, making money [to afford more pleasure], intellectual activity, and ultimately happiness. ${ }^{13}$ Kant knows that a will that is devoid of immediate concern with everyday human actions becomes a 'ghost' that is caught between the phenomenal and the noumenal world - "...for between its a priori principle, which is formal, and its a posteriori motive which is material, the will stands, so to speak, at a parting of the ways; and since it must be determined by some principle, it will have to be determined by the formal principle of volition when an action is done

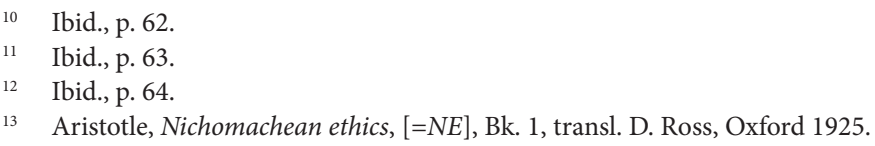


from duty". ${ }^{14}$ The result of the separation of good will from the phenomenal world is that the notion of good will becomes empty; it effectively has no content that would tie it to human actions. In order to remedy the situation Kant needs to further explain his notion of good will. He goes on to define it in terms of another concept, that of duty; more specifically, he claims that a good will is that which acts only for the sake of duty. To explain his concept of duty more exactly, he makes a further distinction between acting for the sake of duty [or from duty] and acting in accordance with duty. The difference between these two kinds of act lies in the intention of the person that performs them. If an act is done purely for the sake of duty then it has moral worth. If, instead, an act is done in accordance with duty, then it is not a morally worthy act even though it appears to be - it has only prudential worth. An example of the first action would be a shopkeeper who does not overcharge his customers because this would be the wrong thing to do, and of the second action would be a shopkeeper who does not overcharge his customers because he wants his business to flourish. Obviously, in the latter case a person is interested primarily in his own benefit, and therefore his action simply does not have moral worth.

But what does it mean to act for the sake of duty? According to Kant, the concept of duty is intuited by human beings in their everyday life and it is experienced as an obligation - a sense of 'ought'. But because we experience obligation only with regard to a law, Kant defines duty "as the necessity to act out of reverence for the law". ${ }^{15}$ Furthermore, we have the capacity to have a feeling of reverence for the law only by virtue of our rationality - "nothing but the idea of the law in itself, which admittedly is present only in rational being ... is the ground determining the will". ${ }^{16}$ In short, Kant starts with the notion of a good will as the absolutely unqualified good, he then defines good will in terms of acting for the sake of duty, and finally, he defines duty as a necessity of acting out

GMM, p. 68.

Ibid., p. 68 .

Ibid., p. 69. 
of a reverence for the law - an action which is possible solely by virtue of our rationality.

Now, we experience a sense of obligation because our wills are not perfectly good. If our wills were perfectly good, then according to Kant, we would always act for the sake of duty. In other words, if we belonged only to the intelligible world [or if we were purely rational beings] then our wills would be perfectly rational. In such a case we would always act according to the law promulgated by our reason, that is, our wills would be in perfect agreement with the law and so we would never experience obligation. As it stands, we belong to both the material and the intelligible worlds: as beings belonging to the material world our wills are influenced by our physical and emotional nature with its inclinations and desires, but as beings belonging to the intelligible world we experience the sense of obligation to follow the moral law.

This sense of an 'ought' is experienced in us as a command whose formula presents itself to us in the form of an imperative. Kant distinguishes between two kinds of imperatives: hypothetical and categorical. ${ }^{17}$ Within the hypothetical imperatives he further distinguishes imperatives of skill and assertoric imperatives. An example of the first would be: if you want to do such and such, you ought to do such and such - if you want to speak French you must study it. Assertoric imperatives refer to certain truths about the human condition such as health or happiness, and assert that some definite actions need to be taken to fulfill that truth: you desire health therefore you must exercise. The common feature of all hypothetical imperatives is that they are conditional. As such they deal with the part of human life that belongs to the phenomenal world that is governed by predictable laws.

In contrast to hypothetical imperatives, moral principles must not be in any way contingent, and so cannot come from the phenomenal world. They must be necessary and universally binding, and thus they must belong to the intelligible world, that is, they must be promulgated by reason. And it is to this world that the Categorical Imperative belongs. It is, 
according to Kant, the only true moral imperative and thus the ultimate criterion of the moral worthiness of an action. Kant gives several formulations of the categorical imperative but its best-known formulation states "Act only on that maxim through which you can at the same time will that it should become a universal law".18

What exactly does Kant mean by this? We all act according to certain principles, for example: lying is wrong, breaking promises is wrong, being honest is good, I will support charities only if I can get a tax benefit, or I will break a promise when it is convenient to me. Kant calls these subjective principles of our action maxims. He claims that if I can universalize my maxim, that is, if I can truly wish that all rational beings should act on this maxim, then it can become a principle of the moral law that is binding for all rational beings.

The test to decide whether my personal maxim can be universalized is to see if it is logically or self-contradictory. If it fails this test then it can never become the principle of the moral law. Kant provides several examples to illustrate his point. For example, I say to myself: I will make a promise that I know I will break. Now I have to subject this maxim to the test. I ask myself if I can universalize this maxim and thus make it a principle of the universal moral law. Can I really will that everyone should act according to my maxim, and what would happen if they, in fact, did? I realize that if everyone decided to make promises they never intended to keep, then making promises would become meaningless simply because no one would believe a person making a promise. The worst scenario would be that eventually people would stop believing each other when it comes to promise - a sad and cynical scenario. So in Kant's view it is simply logically impossible to wish to universalize this rule and so it cannot become a principle of the universal moral law. Thus far it looks as though Kant is correct in claiming we can never will to universalize the idea of breaking promises without being logically or self-contradictory. It seems that Kant's criterion of morally worthy 
action is not only rational but also feasible; it seems to provide us with the straightforward standard of action.

We could only wish making moral decisions were this simple. The problem that Kant faces is rooted ultimately in the foundations of his moral philosophy. It is rooted in the fact that Kant forever cleaves the phenomenal from the noumenal world. He places the entire worth of human action in following the law - in following it absolutely and without any exceptions. This is not only extreme but also morally questionable. Later Kierkegaard would beautifully argue for the teleological suspension of the ethical with respect to Abraham's sacrifice of Isaac. ${ }^{19}$ According to the rule of law Abraham should be considered a plain murderer. But given Abraham's profound rootedness in the moral law, his action has to be seen in different perspective, namely that of deep faith. But we can easily envision a less extreme situation, for example, one where lying or breaking a promise may be in fact morally good [although in Kant's view it could not be not morally worthy action]. Let's say an officer in a POW camp is given certain freedoms, for example, he is allowed an occasional visit to town under light supervision. He gives his word that he will always return to the camp, and is told that if he does not do so, no one else will ever be given the same privilege. He makes the promise not to escape and to patiently await the end of the war but he knows that, in spite of repercussions for the rest of the prisoners, he will try to escape at some point. He visits the town many times, keeps his promise and comes back, until one time when he does not. He escapes and is able to join the resistance forces, fight the enemy, and inform the world of abuses going on in the camp. One could try to defend Kant and say that this example again presents only an extreme situation. But for Kant extreme situations do not really matter with respect to moral law; they still belong to the phenomenal world while the moral worth of an action depends entirely on its rationality and rootedness in the noumenal world. 


\subsection{Moral will and reason}

Let us go back to Kant's notion of a good will and its relationship to reason. As discussed above, Kant starts with the notion of a good will, which he considers the only unquestionable good, then defines it in terms of duty which is further defined as acting out of reverence for the moral law - conduct that is exclusive to rational beings by virtue of their rationality. But let us now look even more closely at what happens to Kant's notion of will. Kant definitely believes in the existence of will but, like in the rest of his philosophy, he divides will into a purely moral will and a flawed will. Perhaps more precisely, we should say that he speaks of will acting in two different ways. As flawed, will is influenced by inclinations and tendencies of human nature, that is, it is still tied to the phenomenal world. In this sense the will has not discovered its absolute freedom as when it is moral will.

Now, freedom of will, as that which makes morality possible, is according to Kant a necessary postulate of reason, more specifically of pure [a priori] reason in its practical application. As mentioned earlier, pure reason is reason that organizes the phenomenal world according to certain categories of understanding. Pure reason is not a part of the phenomenal world, it belongs exclusively to the noumenal world but it makes the phenomenal world intelligible. In a similar fashion, pure practical reason provides conditions that make morality possible, and freedom of will is one of these necessary conditions which Kant calls postulates of reason. Kant claims there are three postulates of pure practical reason: freedom of will, immortality which is linked to the notion of eternal happiness, and God - discussion of the last two is not directly needed for the purpose of this essay.

Kant's claim that good will is exclusively rational is rigid, but he makes his theory slightly more palatable to our human pride by making good will completely autonomous. It is true that in order for the will to be good it must follow the commands of law. But these commands of law are ultimately the principles of moral law that our wills themselves legislate by testing their own maxims of action. Thus in obeying 
the universal moral law, we in fact obey our own principles of action to the extent that they are purely rational.

The moral will is thus completely subservient to reason. But then what is this will? A will in so far as it is good will ceases to have a will of its own, so to speak. It is basically collapsed into reason. One could say that the only reason good will is the only unquestionable good is that it unquestioningly follows the commands of law. Such a will, if not totally subsumed by reason, becomes at the least completely passive with respect to it. And to the extent that such will does not have any dynamism of its own, it ceases to be a real locus of human action. It would seem that the only dynamism would be the tension between the noumenal and the phenomenal worlds.

Of course, saying that the will must be the locus of human action carries a certain metaphysical weight and ideally needs to be corroborated. I will not try to argue for this position here but I take the notion of will as a locus of human activity at face value. My understanding of this complex issue of will has been guided by the philosophy of Aquinas, ${ }^{20}$ the work of the great thomist, E. Gilson, ${ }^{21}$ and by the analysis of Kant's and Aquinas' concepts of will provided by K. Wojtyła. ${ }^{22}$

However, before I turn to Aquinas' analysis of the will, I would like to look briefly at our own experience of willing. When I say I will something to happen this means I see myself as a possible cause of it; I want to effect something. My awareness of my will is always bound to my experience of my willing this or that object - it is always bound to my desire or wish to effect something. In the act of my willing good or evil I experience my efficacy as a moral agent. I, myself, by the sheer act of willing can be the cause of this particular good or evil - an awesome responsibility.

This is where Kant's view of the will seems inadequate. The will is basically pure reason directed towards action. Since I [the transcendental subject] experience the sense of ought, and thus the freedom to effect

20 St. Thomas Aquinas, Summa theologica. Prima pars [= ST], transl. Fathers of the English Dominican Province, New York 1948.

${ }_{21}$ E. Gilson, The Christian philosophy of St. Thomas Aquinas, New York 1956.

22 K. Wojtyła, Person and community: selected essays, transl. T. Sandok, [in:] Catholic thought from Lublin, v. 4, ed. by A. N. Woznicke, New York 1993. 
a moral act, I am supposed to be the cause of an act. I am supposed to will The Categorical Imperative.

But what is the will? What does the will mean? To answer this, I will now turn to Aquinas' analysis of the will and its relation to reason. It is my contention that Aquinas provides not only a more profound analysis of the will and its relationship to reason but also one that rings true phenomenologically.

\section{Aquinas' notions of reason and will}

Similarly to Kant's notion of good will, Aquinas's concept of will cannot be separated from his notion of reason. According to Aquinas, will is the rational appetite, which basically means that will as 'appetite' is the form of desire, but, as rational, will is guided by intellect. However, in order to truly appreciate the depth of Aquinas' notion of will, and its function in moral action we need to go back to his Treatise on man in Summa theologica, ${ }^{23}$ specifically to his discussion of human soul and its faculties, that is, human being's fundamental powers or capacities. In other words, we need to look at his analysis of what makes a human being who and what he is and what distinguishes a human being from other animals. Aquinas' analysis of human soul is rooted in Aristotle' concept of the soul ${ }^{24}$ but he develops it further; most notably, he clarifies the distinction between active and passive roles of the intellect. He also fully develops the concept of human will and thoroughly analyzes its relation to the intellect, and the interplay of intellect and will in moral action.

\subsection{The human soul and its powers}

According to Aquinas, the human soul is the substantial form of the body. ${ }^{25}$ It is the first act and the form or the essence of human being. It

\footnotetext{
23 ST, QQ 75-102.

24 Aristotle, De anima, [= DA], transl. J. A. Smith, New York 1941.

25 ST, Q 75.
} 
is important to note that as the form and the first act of the body, ${ }^{26}$ the soul is not reducible to physical body but it is its immaterial form. It can be interpreted as the information, which, being immaterial, becomes encoded in the physical body and makes it such and such, that is, an individual human body. ${ }^{27}$ The soul is thus what makes a physical body capable of becoming a human body, ${ }^{28}$ a human being; that is, the soul is what makes the human being human.

Being the form of the human body ${ }^{29}$ implies that the soul and body are one, that is, they are not two different entities accidentally joined with each other but they are a unity or a composite. ${ }^{30}$ There is no substantial separation between the intellect and the body, and thus no artificial interaction problem. ${ }^{31}$ The notion of the unity of body and soul has enormous implication for the capacities of the human intellect and the possibility of scientific knowledge, ${ }^{32}$ as well as for the interaction between the rational and sensitive powers or capacities of human soul. The notion of the informed body provides the explanatory foundation for the interaction between the intellect and the senses. For Aquinas, just as for Aristotle, there is no doubt that human reason is able to have knowledge of the physical universe; moreover, the unity of body and soul explains how the intellect or reason ${ }^{33}$ influences our actions and

26 Ibid.

27 For Aristotle, there is no physical body, unless it is already informed, that is, all physical bodies are already defined by their form. This does not mean that they are completely actualized [see Aristotle's distinction between primary and secondary actuality]. Prime matter is pure potentiality, that is, has not being unless it is informed.

${ }^{28} D A$, [Not all physical bodies are potentially alive or human. Potentiality of matter determines its capability to become such and such a body].

${ }_{29}$ Using more modern terminology, the soul can be thought of as the information encoded in a physical body that has potentiality to become a living human being.

30 ST, Q 76, A 1.

31 The so-called interaction problem was already haunting ancient philosophers but it became a staple of philosophical debates since Descartes. One of Aristotle's goals in De anima was to get rid of it by introducing the concept of the unity of form and body.

32 ST, Q 79, Q 84-89.

33 For Aquinas, intellect and reason are the same. Reasoning is one of the operations of the human intellect; it is a stepwise process of going from the first principles to a conclusion, 
more importantly our moral actions. This becomes evident in Aquinas' analysis of the will and free will.

Before I embark on Aquinas' analysis of the will, I will briefly discuss the soul's powers. ${ }^{34}$ Aquinas devotes several chapters to the discussion of the powers of the soul. He sets the stage for the detailed analysis of the specific powers by discussing the powers of the soul in general. ${ }^{35}$ Aquinas' arguments are as usual very intricate, but he basically argues that there are several powers of the soul which are ordered with regard to their nature. The soul is not the subject of all its powers because some are the powers of the composite of body and soul. The soul is the principle of all its powers, that is, all of soul's powers proceed from its essence. The powers are differentiated by their proper objects, that is, each power is directed to its proper object. This also means that no accidental object can differentiate the powers. ${ }^{36}$ Aquinas employs Aristotle's principle that the object reveals the act and the act manifests the power that makes it possible. ${ }^{37}$ Aquinas starts with the notion of the power but the principle is the same. A power is directed towards the act.

Wherefore we seek to know the nature of a power from the act to which it is directed, and consequently the nature of a power is diversified, as the nature of the act is diversified. Now the nature of an act is diversified according to the various natures of the objects. For every act is either of an active power or of a passive power. Now, the object is to the act of a passive power, as the principle and moving cause ... to the act of an active power, the object is a term and end. ${ }^{38}$

and back to incorporate more information to form an improved conclusion. The other operation is understanding which involves direct or immediate apprehension of truth. ST, Q 79.

${ }^{34}$ The soul's powers can be thought of as fundamental capacities of human being that are rooted in his human nature.

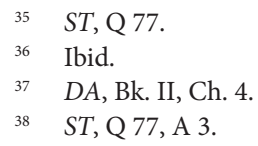


The idea that the operation of each power is determined or defined by its proper object is crucial to the understanding of the operation of the intellect and will and of their mutual interaction. The detailed analysis of all powers of the soul is not the purpose of this essay, nevertheless there are several aspects of the soul's powers that need to be mentioned in order to grasp Aquinas' concept of the will as the rational appetite.

Aquinas distinguishes five genera or kinds of specific powers of the soul: the vegetative, the sensitive, the appetitive, the locomotive, and the intellectual. ${ }^{39}$ The specific powers are differentiated by virtue of their operations and consequently their relationship to their objects. The object of the operations of the vegetative power is the individual corporeal body with which the soul is united. The object of the sensitive power is every sensible body. The object of the intellectual power is the most simple because it is all being in universal. According to the principle, "the higher the power, the more universal the object", ${ }^{40}$ the rational power, by virtue of its proper object being most simple, is superior to and encompasses $^{41}$ all other powers.

Another aspect of the relation between the soul's powers and their objects is based on the principle that "whatever operates must in some way be united to the object about which it operates" ${ }^{42}$ This means that the object of the soul's operation and the soul must be somehow related, and Aquinas says they are related in twofold manner. First, the extrinsic object has the natural aptitude for the soul. The sensible object has natural affinity for the sensitive power [it is its proper object]. And the most common object, the universal, is the object

39 Ibid., Q 78, A 1. Three of the powers - the vegetative, the sensitive, and the rational - also denote the degree of living, the rational being the highest.

40 Ibid.

${ }^{41}$ For both Aristotle and Aquinas there is only one soul [the first act] of the body. There are no different souls, but a higher soul encompasses the lower souls. The sensitive soul encompasses the vegetative soul and the rational soul encompasses both the sensitive and vegetative souls. The vegetative soul is the lowest because the object of its operations is the corporal body to which is united and so also the least simple. The sensitive soul is higher because the object of its operations is every sensible body.

$42 \quad S T$, Q 78, A 1. 
of the intellectual power. Second, the soul has affinity for the object. This happens in the case of the appetitive and the locomotive powers. Through the appetitive power, the soul sees the object as the end, which is also the first intention. And through the locomotive power, the soul pursues an object as the term of its operation and movement. Aquinas, like Aristotle, emphasizes the fact that "every animal is moved for the purpose of realizing its desires and intentions". ${ }^{43}$ As we can see, Aquinas is building the case for his later argument that the will is the rational appetite.

\subsection{The intellect}

Since the intellectual soul is what distinguishes human being from other animals, it is not surprising that Aquinas spends much time ${ }^{44}$ explaining the intellectual power. It is invaluable to study his arguments in detail, however, for the purpose of this essay I will highlight only some aspects of his notion of the intellect. The human intellect is a power of the human soul but not its essence. ${ }^{45}$ It is a passive power. ${ }^{46}$ In this case, passive means being in potentiality to receive something without being deprived of anything. ${ }^{47}$ What this basically means is that human intellect is not capable of apprehending and understanding all being [all reality] at once. Only infinite intellect [God], whose essence is pure act of understanding, knows all being. Human beings are first in potentiality to understand, and only afterwards do they actually understand. But if

43 Ibid.

44 Ibid., Q 79; Aquinas devotes all thirteen articles in Q 79 to the discussion of the intellectual powers.

45 Ibid., If the intellect were the essence, then "that which operates would be the same as the principle of operation, when operation itself is its being". In other words, if the intellect were the essence, and if the intellect were in act [in operation], then the essence would be in act [operation]. This would mean that the human intellect would always be in the act of understanding - it would be always understanding, which of course is not true of humans but only of God. Therefore, human intellect is not the essence but a power of the soul.

46 Ibid., A 2.

47 Ibid. This is the third sense of what it means to be passive. 
the intellect is a passive power and only in potentiality to understand, then how is it that it actually understands?

Aquinas does a beautiful job by providing a novel explanation ${ }^{48}$ which also clarifies and develops Aristotle's notions of the possible and actual intellect. He provides the bridge between the sensible forms apprehended through the sensitive power and the intellect. This bridge is the active intellect, whose function is to abstract intelligible species, that is, the universal aspect of things, and present them to the passive intellect. The passive intellect is in potentiality to receive these intelligible forms, that is, to understand them and become in the possession of knowledge. In other words, the passive intellect is actualized by the intelligible species presented to it by the active intellect that obtained these species via abstraction from the sensible forms, and which, in turn had been apprehended by the sensitive power. ${ }^{49}$ The active intellect is necessary as the link between the sensible and the intelligible worlds because the passive intellect, by virtue of its immateriality and the immateriality of its objects [ideas, concepts] is not sufficient to provide knowledge of the sensible world. But human intellect has only imperfect understanding because it does not understand everything and also because whatever it can understand, it understands in stepwise fashion, as it goes from the potentiality to act. "It reaches to the understanding of truth by arguing, with a certain amount of reasoning and movement." 50

Thus for Aquinas, the intellectual power is capable of knowing reality, albeit in a stepwise process. The notion that the intellectual power by its very nature can discover truth about reality has enormous implications for both scientific knowledge and morality. Before I turn to the appetitive power and the will, there are several points that need

48 Ibid., A 2, A 3. It is in the analysis of the passive and active intellect that Aquinas' genius shines as he clarifies and develops Aristotle's notion of the potential and his somewhat confusing notion of actual intellect. Aquinas explains that active intellect is not what Aristotle meant by actual intellect. The active intellect is that by which things are made to be in act. Actual intellect is in act, it is always understanding.

49 See ibid. A 4, for more detailed analysis of the active intellect.

50 Ibid. 
mentioning about the intellectual power. First, Aquinas explains that the intellect and reason are not two distinct powers. Since human beings are not capable of simple apprehension of the entire truth, reason is the way to reach truth by advancing from one understood truth to another. Thus, compared to understanding, which is rest and possession of knowledge, reasoning is movement and acquisition of knowledge. ${ }^{51}$ Second, the speculative and practical intellects are not separate powers ${ }^{52}$ but the same intellect that is employed to two different ends. The reason they are not two distinct powers is that what is accidental to the object of the power does not differentiate that power. The object of the intellect is being and truth. But it is simply accidental to the intellect that its knowledge is used for speculative or practical purposes. The speculative intellect directs its knowledge towards consideration of truth and the practical intellect towards operation. ${ }^{53}$ Having different ends, which for the speculative intellect is being and truth, and for the practical is the good, does not differentiate the power itself. The fact that it is one intellect employed to two different ends can actually explain that truth and good include one another.

...for truth is something good, otherwise it would not be desirable; and good is something true, otherwise it would not be intelligible. Therefore, as the object of the appetite may be something true, as having the aspect of good,... so the object of the practical intellect is good directed to the operation, and under the aspect of truth. ${ }^{54}$

Thus, there is a mutual relationship between truth and good. This leads us to the further consideration of the relation between the intellect and the appetitive power and finally to Aquinas' notion of the will as the rational appetite.

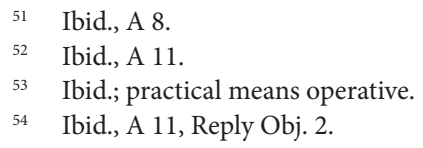




\subsection{The appetitive power}

We can observe that things behave in a certain predictable or determined way, which points to another power of the soul, namely the appetitive power. According to Aquinas [and Aristotle], the inclination of things to behave a certain way is determined by their form. ${ }^{55}$ The most basic kind of inclination is the natural appetite, followed by the sensitive appetite, and finally by the rational appetite - the will, which belongs exclusively to human beings. The natural appetite belongs to all things but it completely determines only things which have no capacity for either sensitive or intellectual knowledge. For example, the fact that the stone falls if it is thrown up into the air is due to its physical nature. We presently have a more sophisticated explanation of this event in terms of different forces acting upon a physical body [gravity], but the main point is that our bodies, in so far as they are physical, must act according to what they are - that is, by virtue of being physical they must follow certain physical laws. In this sense, stones, plants, and the rest of the inanimate universe are completely determined by their nature [physical laws]. This seems to be the case even for the fundamental subatomic particles. They may not have so-called 'classical' properties, nevertheless they are defined by their spin, charge, or flavor. We may put various modern names on these 'forms' but it does not change the fact their 'forms' determine the behavior of these entities.

The situation is different for things that have capacity for knowledge, that is, for all things that have the sensitive and intellectual powers. They are determined by their natural form but they are also receptive to the forms of other things: "senses receive sensible forms, and the intellect receives the intelligible species." ${ }^{56}$ Thus, things that have capacity for knowledge, besides the natural inclination, also have another inclination, the appetitive power, which is based in their capacity to know. By virtue of this appetitive power, animals not only react to stimuli but are

55 Ibid., Q 80, A 1.

56 Ibid. 
also able to desire what they apprehend, pursue what is good for them, and avoid what is bad for their survival and well being.

Aquinas further distinguishes between the sensitive appetite and the intellectual [rational] appetite. The difference between them is rooted in the different kind of object of their respective appetites. The appetitive power is passive which means it is moved by its object. Thus, even though both the sensitive and the intellectual appetites have to be moved [affected] by their objects in order to be in act, the objects that move them are different by nature. That is, the sensitive appetite is moved by virtue of desiring the individual sensible object. But the intellectual appetite, although it desires the individual thing, does so under the universal aspect, for example it can desire good or virtue.

The natural inclination [appetite] belongs to all things by their nature but it fully determines only some things, the sensitive appetite belongs to animals including humans [insofar as humans are animals] but it fully determines only the behavior of non-rational animals. Human beings have the intellectual power, that is, the form of their being is the intellectual soul. And because inclinations stem from the form of a thing, this implies that human-being appetitive power is rooted in their rational nature. This further implies that their behavior is not entirely determined by their sensitive appetite. ${ }^{57}$

\subsection{The will - the intellectual [rational] appetite}

We have finally come to Aquinas' analysis of the will. ${ }^{58} \mathrm{He}$ addresses the question of will at the end of the analysis of all of the soul's powers. This makes sense because, in order to really understand the nature and function of the will, we need the background of the other powers, especially the intellectual and the appetitive. He starts by discussing the

57 Ibid. Aquinas discusses one more power, the power of sensuality which is divided into the concupiscible and irrascible appetite. They are the powers of the sensitive appetites but in rational animals [humans] they obey both reason and will.

58 Ibid., Q 82, A 1. 
appetitive or the desiring aspect of the will. Is there something that the will must desire? That is, is there the proper object of the will that determines it in a similar way that the other powers of the soul were determined by their proper objects? Does the will have to desire all that it desires necessarily? In other words, is the will determined by any object that it desires? This would make the will a prisoner of the objects it desires. In what way does the intellect offer assistance to the will? And since the will is the rational appetite, what is the relation between the will and reason?

Aquinas analyzes several types of necessity in order to show, if there is any necessity for the will, what kind of necessity it is. Something is considered necessary if it must be. ${ }^{59}$ We can distinguish two main kinds of necessity: internal and external. The internal necessity is due either to the material principle [e.g., all living things die] or the formal principle [e.g., the sum of the three angles of the triangle are equal to that of two right angles]. The external necessity may be the necessity 'of the end' or 'of the agent'. In the case of the necessity of the end, which is also called utility, something is necessary because without it the end cannot be attained or not easily attained; for example, food is necessary for life. ${ }^{60}$ The necessity 'of the agent' means that someone is forced by an agent so that he is not able to do otherwise. This necessity is also called the necessity of coercion.

Aquinas argues that the necessity of coercion is repugnant to the will because this would mean that something would be voluntary and coerced at the same time. ${ }^{61}$ Just as a thing is called natural because it is according to its natural inclination, the will is called voluntary if is in accordance with its inclination. The will is an inclination towards something. Therefore just as a thing cannot be at the same time violent and natural [that is, be against the natural inclination of its own nature], so

59 Ibid.

${ }^{60}$ The necessity of the end is the closest to Kant's hypothetical and assertoric imperatives.

${ }_{61}$ ST, Q 82, A 1. 
something cannot be voluntary and coerced. In short, it is against the nature of the will to agree to being coerced.

However, the necessity of the end is not repugnant to the will, for example if there is only one way that something can be accomplished. And neither is the natural necessity repugnant to the will.

...for as the intellect of necessity adheres to the first principles, the will must of necessity adhere to the last end, which is happiness: since the end is in practical matters what the principle is in speculative matters. ${ }^{62}$

Thus the will indeed desires something necessarily - it desires happiness, but this means that it is determined by it. The will is not coerced but neither is the will absolutely free. The will is free but its freedom, as Aquinas explains later, ${ }^{63}$ is not the freedom in regard to its last end but the freedom to choose the means to reach the end of an action.

However, that the will has natural necessity [inclination] toward the last end, which is happiness, does not imply that whatever the will desires it must necessarily desire. That is, except for happiness the will does not desire of necessity anything else that it desires. Aquinas demonstrates this by making an analogy with the intellect. Just as the intellect adheres necessarily to the first principles, so the will necessarily desires happiness. However, there are some intelligible things do not have necessary connection with the first principles, for example, contingent propositions. ${ }^{64}$ And there are some principles such as demonstrable conclusions that do have a necessary connection with the first principles; however, the necessity of this connection has to be shown so that the intellect can assent to it. The will necessarily desires happiness but there are many goods that do not have the necessary connection with happiness because human being can be happy without them, and thus the will does

62 Ibid.

63 Ibid., Q 83.

64 Ibid., Q 82, A 1. Denial of contingent propositions does not involve the denial of the first principles. 
not will them necessarily. Therefore "the will does not desire of necessity whatever it desires." ${ }^{65}$ As the rational appetite, the will has the capacity to regard the universal and perfect good, therefore its capacity is not subjected to any individual good. That is, by virtue of being the rational appetite, the will desires everything under the universal aspect of good but it is not determined by one individual good. In short, the will of necessity desires happiness, and in that sense it is determined by it. As the appetitive power, the will desires the good but there are many different goods. We always desire what we think is good for us, however we may be wrong as to what the true good is for us. Because the will, as the rational appetite, regards the good under the universal aspect, it is not determined by any individual good.

Since the will is the rational appetite, what is the relationship between the will and reason? Is the will superior to reason, or is the reason higher than the will? Aquinas explains that in the absolute sense the intellect is always superior to the will, but in the relative sense it is not always so. ${ }^{66}$ Superiority of one thing over another can be considered in two ways: as absolute or as relative. A thing is superior absolutely when it is considered superior in itself, that is, in its essence, but it is relatively superior when considered with respect to something else. If the intellect and the will are considered in regard to themselves, that is, in their own being [essence], then the intellect is the higher power. This is obvious when their respective objects are compared. Based on the principle that "the more simple and the more abstract the things is, the nobler and higher it is in itself" 67 it can be seen that the object of the intellect, which is the idea of the desirable, is more simple and therefore superior to the object of the will, which is the desirable itself. And since the nature of the power is determined by its proper object, it is obvious that the intellect

65 There is one qualification that has to be made. Aquinas actually argues that there are some things that are necessarily connected with happiness which is God, but unless we are blessed with the Divine Vision, we do not see this necessary connection. And this is why the will, except for happiness, does not desire anything else necessarily.

66 ST, Q 82, A 3.

67 Ibid. 
in itself is a higher power than the will. However, when the will and the intellect are considered relative to each other, then the will is sometimes superior to the intellect.

But relatively and by comparison with something else, we find that the will is sometimes higher than the intellect, from the fact that the object of the will occurs in something higher than in which occurs the object of the intellect. ${ }^{68}$

This is quite difficult to unravel so let us bring in Aquinas' example. The love of God is superior to the knowledge of God, but knowledge of a corporeal thing is superior to the love of them. What does this mean? Aquinas explains that in the act of the intellect, the idea of a thing that is understood occurs in the one who understands. But the act of the will tends to the thing itself as existing in itself. In this example, the object of the will is God Himself. The object of the intellect is the idea of God but his idea occurs in the individual intellect. That is, the object of my will is God Himself, but the idea of God is in my individual [and infinitely inferior] intellect, therefore the will is superior to the intellect. But the intellect can also be superior relative to the will, if for example the object of my desire is inferior to the idea that I have in my mind. And this is why Aquinas says that the desire of corporeal things is inferior to the knowledge of them. "Absolutely, however, the intellect is nobler than the will." ${ }^{69}$

Thus we see that the relation between the will and the intellect is complex. Even if in its essence, the intellect is superior, the will by virtue of being the appetitive power and thus being inclined toward its object, has its own movement or dynamism. Again the relation between the will and reason is complex here. Does the intellect move the will or does the will move the intellect? The thing is said to move as an end or as an agent. ${ }^{70}$ The intellect moves the will as an end. The reason is that

\footnotetext{
68 Ibid.

69 Ibid.

70 Ibid., A 4.
} 
the good that is understood by the intellect is the object of the will and so it moves the will as an end. That is, the will tends towards the good that is presented to it by the intellect. The will wants to obtain it and so it is moved by it as an end. On the other hand, the will moves the intellect and all other powers of the soul as an agent. This is based on the principle that "the power which regards the universal end moves the powers that regard the particular ends" ${ }^{71}$ The will moves the intellect and all other powers as an agent because the will's object is the good and the end in general. All other powers have as their object specific ends, including the intellect whose proper object is the knowledge of truth. It is then clear that the will, as the power that desires good in general, will move all other powers to their respective ends.

The relationship between the will and the intellect can be viewed in yet another way. Each of them can be seen either in terms of its proper object or as a power of the soul with a determinate act. The object of intellect is the universal being and truth, and of the will it is the universal good. This offers several possibilities for the relationship between the two powers. First, if we compare the respective objects of the intellect and the will, then the intellect is superior to the will, as we have already observed. Second, if we compare the universal nature of the object of the intellect and the determinate nature of the will as the soul's power, the intellect is still superior to the will. Third, however, this changes the dynamics between the powers because if we consider the will in its common nature as desiring the universal good, and the intellect as a particular power of the soul, then the will is superior to the intellect. And we can see how it can move the intellect and other powers of the soul as well. Aquinas concludes:

From this we can easily understand why these powers include one another in their acts, because the intellect understands that the will wills, and the will wills the intellect to understand. In the same way good is contained in truth, inasmuch as it is an understood truth, and truth in good, inasmuch as it is a desired good. ${ }^{72}$

$71 \quad$ Ibid.

72 Ibid., Reply Obj. 1. 
The intellect, whose proper object is superior to the will, encompasses the will and thus it understands its role in the soul. But if the intellect is viewed as the particular power of the soul, then the will whose object is good in general is superior to the intellect. Their mutual relationship also explains the reciprocal relationship between the truth and good. The intellect's object, being and truth, is superior to the will's object, the good, and therefore understands it. But as the desired good, the truth becomes the object of the will. Thus, the will and the intellect are both in the proverbial driver's seat. It is true that the intellect, by virtue of the simplicity of its proper objects, the universal being and truth, has absolute superiority with regard to the will. Nevertheless, the will, by virtue of its inclination and desire for the good in general, holds its own in regard to intellect and of all other powers of the soul.

It is impossible not to appreciate the complexity and profoundness, and yet amazing simplicity of Aquinas' explanations. The next part of Aquinas' analysis, his concept of the free-will, will bring us back to the final topic of the discussion, namely, the implication of Kant's and Aquinas' notions of the will for the criteria of the moral action.

\subsection{Free-will}

There is no doubt in Aquinas' mind that human beings have free-will. If they did not, then all commands, punishments, exhortations would be senseless. ${ }^{73}$ But free-will belongs only to rational beings, that is humans. The free-will is connected with the capability to judge using our reason and to choose among the alternatives. It is clear that some things, like inanimate things [a stone falling to earth], do not have the power of judgment. The non-rational animals have judgment that comes from their natural instinct, but not free judgment. Only human beings have the capacity for free-judgment that is rooted in intellect, as shown by the fact they can compare, deliberate, and judge between different options. But this capacity for the freedom to deliberate, choose, and act 
accordingly does not imply that human being is the cause of himself. Being the cause of one's acts or acts of others does not necessarily imply being the first cause. The free-will is not the cause of oneself but only of one's own actions.

But what is the free-will? We feel it, we assume it, we have the capacity to choose between options. ${ }^{74}$ Free-will is not a habit, that is, a certain [good or evil] disposition to act a certain way, because free-will is indifferent to good or evil choice. Free-will does not tell me whether something is good or evil.

The proper act of free-will is choice, so in order to learn more about free-will we must look at the nature of choice. Free choice has two aspects: cognitive and appetitive. Cognitive involves the judgment of reason whether to prefer one thing to another. The appetitive involves the acceptance of the judgment of reason and it chooses the means to obtain the end that are seen as useful. Now, useful comes under the category of good, it is a kind of good we need to accomplish or obtain the desired end. But since good as such is the object of the appetitive power, this means free-will is the appetitive power.

Thus an act of free-will is free-choice and it involves both the cognitive and appetitive aspects. But how does the will choose its object and act upon it? The process of selection involves both reason and will and consists of several stages: intention, reason's counsel, deliberation, judgment, the will's consent, and finally an act of election. ${ }^{75}$ Intention is the will's movement towards its object. The intellect presents an object to the will but it is only the will that is capable of desiring. The object is the end - the goal of will's desiring, but in willing its goal, the will also wills the means to accomplish it. Intention is thus one act that includes both the end and the means to it. For example, in my wanting to be a medical doctor I also will the means to become one. The choice of the means is usually quite complex, and it is done by the intellect through the process of deliberation that

$74 \quad$ Having the capacity does not mean we always choose what we want, because there are factors involved, for example the necessity of coercion.

75 E. Gilson, The Christian philosophy of St. Thomas Aquinas, op. cit., Part. III, Ch. 1. 
is called counsel. The deliberation ends in a judgment. In other words, I desire a certain goal, I look at different options of how to obtain it, and finally I reach a certain conclusion as to how I can do it. My will is involved in intending the goal, but the deliberation and the judgment are performed by the intellect. But, now, the will has to give its consent to the result of deliberation - it has to approve the judgment of the intellect. Usually there are many possible ways to obtain the desired end, and the will may give its consent to several judgments; however, at any given time, only one course of action is possible. And it is the will that ultimately chooses in the act of election, the course of an action.

Aquinas discusses free-will right after the will. ${ }^{76}$ This is appropriate because will and free-will are one power similarly to intellect and reason being one power. Just as intellectual apprehension consists of the simple act of understanding and then reasoning in a stepwise process, to will implies the simple appetite for something and free-will is the act of choosing the means to obtain the end. The will regards the end as desired for itself, and the free-will regards the means to obtaining the end. Just as reasoning is the act of the intellect, so free-choice is thus the act of free-will.

Now, Aquinas agrees with Aristotle ${ }^{77}$ that we always act for the sake of some end. Our actions are always done with some goal in mind. Aquinas shows that the intellect and the will are both actively involved in this act, which he calls the human act. The intellect and the will reciprocally affect each other but they always remain separate from each other in their function. Understanding affects the will by presenting a given object to it, but ultimately it is the will that chooses to pursue it or not. Based on this rendering of Aquinas' analysis of the human act, we can see that he clearly keeps these two faculties of the human soul distinct. Each faculty has its definite function: the intellect's is to understand being and pursue the truth, and the will's is to desire the good as such. They constantly influence each other but each of them never loses its own identity.

76 ST, Q 83.

77 NE, Bk. 1, Ch 1., p. 935. 


\section{Discussion}

Because reason plays a crucial role in Kant's and Aquinas's interpretations of the will, let us take a brief look at their main disagreement as to the nature of reason. The primary difference lies not so much in the limits of knowledge as in the limits of our intellect. For Aquinas the intellect can know physical things as they are, even if this knowledge is imperfect and has to be constantly adjusted; for Kant, on the other hand, the knowledge of things-in-themselves is impossible.

Aquinas' view is based on two things: first, physical things have general forms or natures, which manifest themselves through their inclinations. ${ }^{78}$ Second, the intellect can discover the truth about things. Even though the sensible natures or forms of things are not intelligible, ${ }^{79}$ the intellect is capable of knowing things by abstracting the general aspects from the sensible forms [active intellect] and forming intelligible species [concepts]. Understanding and reasoning are two ways the intellect can know things. ${ }^{80}$ Can, according to Aquinas, reason have absolute or complete knowledge of reality? No, because human beings are imperfect and therefore our understanding is imperfect. We do not have infinite intellects and therefore we cannot have absolute knowledge of reality. If we could this would mean becoming God, since only God is absolute understanding and knowledge of all reality. Nevertheless, by virtue of having the active intellect, the human being has the power of reaching to the heart of things. ${ }^{81}$ Aquinas never doubts that we can know things even if we discover their being only gradually. He never doubts that we

${ }^{78}$ Interestingly enough, Aquinas' explanation is still applicable today, not in terms of scientific details but in terms of general explanatory principles [form] that account for the general tendencies of things.

79 ST, Q 79, A 3.

${ }^{80}$ Ibid., A 8. Understanding is simple apprehension of the first principle and reasoning is a gradual progression in knowledge of things: "human reasoning by way of inquiry and discovery, advances from certain things simply understood - namely, the first principles, and again, by way of judgment returns to by analysis to first principles, in the light of which it examines what it has found."

81 Ibid., A 4. 
can know reality even if we will never have the complete knowledge of it. The crucial thing is that we can know things as they really are. We can touch reality, and in this sense reality reaches to us and envelops us in its truth.

The fact that, even if our knowledge is imperfect, we can know the truth about reality has immense implications for the possibility of having the objective foundation for the criterion of the moral action. Moreover, this foundation does not have to be torn away or be separate from the totality of our human nature, instead it can find its dwelling in our humanity, which involves both the intellect and the desire for truth and good - in the rational appetite. The will can have life of its own while listening to reason and appreciating its offering of truth and wisdom.

The fact that the human intellect cannot have absolute knowledge would almost seem to agree with Kant's notion of the impossibility of having knowledge of things-in-themselves. Interestingly enough, even though Kant accepts the impossibility of having knowledge of things-in-themselves, nevertheless he does not give up on having absolutely certain knowledge. This knowledge, however, will concern only the phenomenal world, that is, the world of appearances. To his special brand of skepticism, namely, his doubt in reason's ability to reach things-in-themselves, Kant offers an ingenious solution. He makes the human mind the absolute arbiter of human experience and knowledge, and the will the ultimate judge of the moral worth of actions. This effectively amounts to the same thing, that is, to reason in its a priori form.

Kant's interpretation of reason extends to the will, and it must do so insofar as the will is not will but is pure reason directed to action. The will is split in two: the phenomenal and the moral will. The phenomenal will is determined by practical ends and is expressed in the form of the hypothetical and categorical imperatives [assertoric and of skill]. On the other hand, the moral will, the 'good will', is completely autonomous and free. Even though reason cannot prove this freedom, its existence is necessary and therefore must be assumed for the sake of morality. Thus freedom must exist, even if its existence is only a postulate of pure practical reason. But because the moral will is effectively reason that is 
directed to practical moral applications, the rules of logic seem to be its only constraints. That is, as reason, the will is determined by the rules of logic. This finds its ultimate expression in the Categorical Imperative, ${ }^{82}$ whose function is to safeguard against logical inconsistencies in promulgating the absolute moral law. In this sense the Categorical Imperative is the absolute criterion for the moral will. It is true that some formulations of the Categorical Imperative emphasize the respect for all rational beings by requiring that they should always be treated as ends in themselves and never as means to an end. The respect is rooted in the rational nature of human beings.

And yet, despite this tremendous sense of rationality and duty, and despite the high regard for all rational beings, Kant's notion of will feels strangely empty and cold. It feels divorced from humanity, that is, from what makes humans... well... human, which is not only reason, but reason and desire intertwined in their pursuit of truth and good. It is true that will as directed to its practical matters in the phenomenal world does take human inclinations into account. But even then it is governed by simple practical rules of utility - if you want this, do this, or do this because it makes sense. It feels wooden, or maybe we should say digital since its function is practically analogous to that of the mindless computer, which 'dutifully' follows the commands of the software.

The question then, is how can Kant's will act at all? What makes it act? Even if it wanted to obey the Categorical Imperative, what is going to move the will to obey it? The will is reason but reason, even if it is directed to practical activity, has to have some motivation to be moved to act. Otherwise, reason by itself will only think of steps of how to accomplish a given task but it may never be moved to accomplish it. Kant's solution to this dilemma is again ingenious. Just as he makes the pure a priori reason dynamic by having it impose its categories on the experiential data, so he make the pure practical reason also dynamic under the guise of the will and the good will in regard to morality. 
In contrast to Kant' notions of the will, Aquinas' will is full of life and dynamism of its own. As the appetite it seeks good, but as the intellectual desire it has the capacity to seek the true good. True, it is determined by the last end, that is, happiness or good as such. In this sense it does not have the absolute freedom and autonomy that Kant demands of his notion of the will. Nevertheless, the fact that it is the rational appetite gives it a strong identity of its own. In order to be and to act, the will does not have to collapse into reason. It is exactly by virtue of its desiring, that the will can move the intellect and other powers of the soul. It is precisely because it is the power to pursue the true good that gives it purpose and motivation to act at all. This motivation confers upon it dynamism that Kant's will frankly lacks because it has no will.

But it is also in the notion of the free-will that Aquinas offers a more plausible explanation of our freedom of choice. The will is defined by good in general and is free to choose between alternative means to the end. It is not determined by any particular goods and it is not determined by the means to the end. The will has no absolute autonomy but it is also not completely determined. The will is so very human: it desires, it motivates, it pursues, it moves to action. And in its power to choose either to listen to the intellect's advice or to ignore it, in its choice of the means to the end, free-will brings freedom into our contingent world.

Next to Aquinas' notion of the will, Kant's will appears confused in its identity or rather, it has no identity of its own. This is the case for both the will in its phenomenal or prudential function and the will in its moral function. Both wills are at the service of reason, and effectively have no power of their own. Instead of a continuous play of the intellect and will in which it is sometimes the intellect and sometimes the will that wields an upper hand - a scenario which rings true to our own experience of our actions - Kant's will must somberly follow in the intellect's footsteps. The will must obey reason to the point of ceasing to be itself.

Thus will in its moral function does not seem to fair any better. The good will has no dynamism, no identity of its own, and no power of choice. In fact, in order to qualify as moral, the will has to give up its 
power of choice and dutifully follow reason. And if by any chance it deviates from the strict rule of the Categorical Imperative, it risks descending into the seemingly lower realm of the phenomenal world where it can never have any moral value, only prudential value at best. In contrast to this rigidity in following the law, Aquinas' will follows reason's guidance, counsel, and judgment about the true good, but as the desire for good as such, the will retains its identity as the will. It listens to the counsel of the intellect but it is the will that chooses and acts.

A further question is that of how their respective concepts of will fare in providing the criterion of moral action. When Kant says that an action is moral because it is rational, he must mean that it is morally good as opposed to morally bad - this is the common-sense understanding of something being moral. But what makes it good? For Kant, it must be good because it is rational and it follows the Categorical Imperative. But is being rational, in the sense of being logically consistent, a sufficient criterion of being good? This somehow does not seem adequate.

It is quite conceivable that reason passes a law that is completely rational and therefore passes Kant's test of morally worthy action. But is it in fact moral? Is being able to universalize a maxim a good enough test of moral will? Is its universalizability a sufficient criterion of the moral worth of an action? For example, my subjective principle of action might be that I have to wear a hat every Sunday. It seems there is nothing preventing me from making this maxim universal. There is no logical contradiction in testing it and so it should qualify as a principle of a moral law. But the test that should make it a principle of a moral law fails completely with respect to its content, and thus it also fails in terms of being the ultimate criterion of moral action. It is in fact meaningless. I still do not know if the action of wearing a hat on Sundays is indeed morally good or bad - my common sense tells me that it has nothing to do with morality. But it does pass the Kantian criterion of a morally worthy action. I was able to universalize it and it is not self-contradictory. But the reason that could make this maxim morally good or morally evil completely evades me. In this sense Kant's criterion of the moral worth of an action ultimately fails - it does not exist. 
What exists at best is a test of the logical consistency of my action. ${ }^{83}$ But it is reasonable to expect from the test of the moral worth of an action that it should test not only whether my subjective principle of action is self-contradictory but also whether this principle is truly morally good or evil. How does my action affect me, others, the world? After all, as a moral agent I am responsible for the good or evil I myself bring into this world through my actions. It is somewhat ironic that Kant, in being determined to provide the absolute condition for the possibility of morality, practically makes human moral action impossible. In contrast to Kant's formal rationality, Aquinas explains how moral action is possible in our human world. Both the intellect and the will are dynamic - the intellect in its incessant search for truth, and the will in its desire for the good as such. They fumble and sometimes fail but they constantly seek the true good. This is in stark contrast to Kant's pure practical reason whose main function seems to be trouble shooting for logical inconsistencies, and to Kant's will whose only activity is to obediently follow reason.

But what does it means that my action is morally worthy? From the point of view of common sense, it seems that my action has moral worth if the intention is good, and if, in fact, it effects some good rather than evil in the world. Of course the further question would be what makes something morally good or evil? To this effect we need a more prescriptive standard but we can also discuss the subject in more general terms. According to Aquinas, a human act must be judged not only in regard to its intention, as in Kant, but it has to be assessed in its entirety, that is, its intention, the choice of the means, and its effects in the world. Thus, in order for an act to be considered as morally good, all of the required factors have to be present: the right intention, the right choice of means, and finally, good effects. If one required factor is missing, for example a right intention, then the entire act may become bad. And by the same token, having just one required factor is not sufficient to make the action morally good. On a very mundane level, we can 
think of practicing good habits as an excellent way not only to practice morally good actions but also to become morally good persons. For example, I can choose to get drunk every night and be nasty to my family, or instead I can be sober and try to help my family. By practicing good habits I can actually bring moral good into the world. Thus Aquinas sees moral actions in their totality. His criterion of the moral worth of an action is perhaps more complicated but it is also more realistic. As opposed to Kant's actions that are superhuman in their abstraction, Aquinas's moral actions are performed by real people and take place in the context of the real human world.

How does Kant's criterion of moral worth fare in comparison to that of Aquinas? Kant places the moral criterion of an action outside of the phenomenal world because he wants to remove any possibility of its being tainted by human inclinations or consequences. But Kant's criterion is morally vacuous in the sense that it does not help decide which actions are effectively morally good or evil.

No matter how much we try to transcend our humble existence in the phenomenal world, as long as we have our physical bodies and our inclinations, we are an inextricable part of this world. And this means that our actions have real effects and these can be morally evil or morally good depending on the totality of our acts, which include our intentions and the means we choose to attain our goals. As long as we are not naive and are aware of the power of our will and of our reason, instead of hiding in the ivory tower of Kant's noumenal world, we must take full responsibility for the entire process of our moral acts.

\section{Bibliography}

Aristotle, De anima, transl. J. A. Smith, New York 1941.

Aristotle, Nichomachean ethics, Bk. 1, transl. D. Ross, Oxford 1925.

Coppleston F., A history of philosophy, v. 5, Ch. 16 (3), London 1991.

Gilson E., The Christian philosophy of St. Thomas Aquinas, New York 1956. 
Hume D., Enquiry concerning human understanding, [w:] The english philosophers of the $17^{\text {th }}$ and $18^{\text {th }}$ centuries, New York 1910 (Harvard Classics, 37, ed. Ch. W. Eliot), https://ebooks.adelaide.edu.au/h/hume/david/h92e/.

Kant I., Critique of pure reason, transl. N. Kemp Smith, New York 1965, Preface to the first edition.

Kant I., Groundwork of the metaphysics of morals, transl. H. J. Patton, New York 1964.

Kierkegaard S., Fear and trembling, transl. A. Hannay, Harmondsworth 1985.

Scruton R., Kant: a very short introduction, Oxford 2001.

St. Thomas Aquinas, Summa theologica. Prima pars, transl. Fathers of the English Dominican Province, New York 1948.

Wojtyła K., Person and community: selected essays, transl. T. Sandok, [in:] Catholic thought from Lublin, v. 4, ed. by A. N. Woznicke, New York 1993. 